Published in Leslie Armijo and Saori Katada (eds., 2014), Financial Statecraft of Emerging Powers, Houndmills, Basingstoke: Palgrave Macmillan, pp. 103-137.

\title{
All Politics is Local: \\ The Renminbi's Prospects as a Future Global Currency
}

\author{
Ulrich Volz*
}

This version: 14 December 2013

* Address for correspondence: Department of Economics, SOAS, University of London, Thornhaugh Street, London WC1H 0XG, UK. Tel: +44 (0)207 898 4721. E-mail: uv1 @ soas.ac.uk. 


\section{Acknowledgements}

The chapter was largely written while I was a Visiting Professor at Peking University in 2012. The research is based on informal interviews conducted with Chinese officials and scholars at the time. Given the sensitiveness of the topic, the interviewees were promised anonymity. I would like to thank Peking University's School of Economics for its hospitality and Joshua Aizenman, Leslie Elliott Armijo, Shaun Breslin, Benjamin Jerry Cohen, Hiro Ito, Saori Katada, Arthur Kroeber, Michael Pettis, as well as participants of the two workshops on "Financial Statecraft and Ascendant Powers", held at the University of Southern California on April 5, 2012, and July 28, 2012, for very helpful discussions and comments on previous versions of this paper. The usual disclaimer applies. 
Recent years have seen a heated discussion over Chinese capital account liberalization and internationalization of China's currency, the renminbi (RMB). Against the backdrop of a weak US economy and China's growing international economic clout, there has been speculation about the RMB replacing the US dollar as the world's leading currency. Subramanian (2011: 1), for instance, maintains that "the renminbi could become the premier reserve currency by the end of this decade, or early next decade". Much of the current discourse recalls past discussions when other currencies, especially the Japanese yen (Burstein 1988, Kwan 1994, Taguchi 1994) and the euro (Chinn and Frankel 2007), were seen as candidates to "dethrone" the dollar.

China is often portrayed as aggressively trying to achieve global leadership, and RMB internationalization is seen by many as the epitome of China's quest for global dominance. However, it is important to understand the complex motivations behind RMB internationalization in order to allow for a more balanced and nuanced debate on China's changing role in the international economy. Understanding the reasons for which China might pursue RMB internationalization also is key to predicting the speed at which it might proceed.

In the context of this volume, what may appear to be a rather assertive, offensive, and systemic use of financial statecraft (FS), through which China would actively be redefining the global currency structure by promoting an increased global use of the RMB and displacing the US dollar, is argued to have additional layers of meaning within China's domestic political economy. As discussed below, RMB internationalization has been triggered mostly by China's domestic need for financial reform along with the country's defensive reaction to its excessive dependence on the US dollar. Hence at present, the Chinese "challenge" to the existing global currency hierarchy through RMB internationalization comes largely from the Chinese reformers' desire to restructure the country's rigid and inefficient financial sector and improve the effectiveness of domestic monetary policy. 
This chapter reviews the current state of RMB internationalization and highlights the links between capital account opening and RMB convertibility, on the one hand, and the controversies within the Chinese Communist Party (CCP) leadership over the speed of economic and financial liberalization, on the other. I argue that the Chinese discussion about RMB internationalization is mainly motivated by domestic debates about financial sector reform. In particular, the widely popular notion of establishing the RMB as a global currency has been promoted by those seeking domestic financial reform as a way to overcome the reform resistance coming from various factions within the Chinese government and economy. International currency policy is therefore primarily used for the purpose of achieving domestic policy goals, rather than for changing the global financial order or supporting larger foreign policy goals. My argument thus relates to earlier literature on China's economic opening and reform, much of which highlighted "domestic politics [as] the primary source of policy changes in China's reform and opening" (Moore 2002: 35).

The chapter is structured as follows. After briefly reviewing the literature on international currencies in Section 1, Section 2 summarizes the incremental steps toward currency internationalization that the Chinese authorities have taken thus far. Section 3 analyzes the political economy of China's domestic financial market and capital account reforms and establishes the link to the discussion on RMB internationalization. It suggests that neither a foreign policy lens nor a purely economic efficiency one captures key elements in the decision-making process of today's Chinese leadership; instead, domestic political economy considerations appear to play a major role. While there are domestic interests that support RMB internationalization, they are opposed by powerful party factions, state-banks, and state-owned enterprise constituencies that perceive themselves as likely to lose from such policies. Section 4 discusses China's broader ambitions to augment its stature in the regional and global economy, and discusses the ways in which FS - the active use of monetary and financial instruments, including promotion of the RMB as an international reserve currency - 
has been employed to pursue this foreign policy goal. My conclusion argues that a rapid and comprehensive liberalization of China's capital account is improbable. It is therefore equally unlikely that the RMB will take on the dollar's role as the premier investment and reserve currency anytime soon, even as the RMB is established as a leading currency for trade. The likeliest scenario in the next two decades is the emergence of a multi-polar international monetary system, with the US dollar, the euro, and the RMB in the lead roles and smaller regional lead currencies in Africa, Latin America, the Middle East, and Central Asia in the second tier.

\section{International reserve and investment currencies}

The international monetary system is characterized by currency competition and a hierarchy of currencies. Cohen (1998: 114) compares currency competition to a "vast, threedimensional pyramid: narrow at the top, where a few popular currencies dominate; increasingly broad below, reflecting varying degrees of competitive inferiority." Several factors establish a currency's rank in this international currency hierarchy, and whether a currency will be able to become a major international or "global" currency, which will be used not only as invoicing currency for trade, but that will also be a major investment currency in the portfolios of international investors and reserve currency held by central banks. ${ }^{1}$

As Minsky (1986: 228) observed, "everyone can create money; the problem is to get it accepted." The easiest way to have one's IOUs accepted is to generate liabilities for others that can only be extinguished through possession of these IOUs (Kregel 2006). A government can domestically enforce the acceptance of its currency through the fiscal system (and up to a

1 Thimann (2010) distinguishes between global and international currencies, where the former are currencies that play a major role in the global economy, while the latter are currencies that are used outside the constituency where they are issued. 
certain degree through its legal system) by creating a tax liability on its citizens that can only be redeemed in the form of money issued by the government. But this does not work internationally, as a government can tax its own citizens, who are subject to government regulations, but cannot force non-residents to hold claims. The only way to make the currency internationally accepted is by building an expectation that these liabilities will act as perfect substitutes for the liabilities of other countries' monetary authorities.

A number of conditions can be identified that contribute to building such expectations. First, confidence in a currency's future value is dependent on the political stability of the country of origin (Cohen 2000). This is the quintessential precondition for establishing a track record of relatively low inflation and low inflation variability. Second, countries need sound and credible fiscal institutions. In conjunction with noninflationary wage and price policies, a sound fiscal framework lays the groundwork for a noninflationary monetary environment with low nominal as well as real interest rates. Third, countries need to establish credible monetary regimes. Unpredictable monetary policy makes market participants unsure about the future real value of their assets issued in domestic currency and may lead them to denominate them in international currency (Jeanne 2005). Establishing a strong, (de facto) independent central bank with strong inflation aversion and a clear monetary policy objective is an important way to pin down inflationary expectations and to reduce this uncertainty.

Fourth, avoiding international debt, and instead striving for a surplus in the trade and current account helps to create expectations of an appreciation of the national currency. From a long-term development perspective, it is not the short-term stabilization of the exchange rate that is of central importance but rather the currency's long-term value. The quality of a nation's currency is undermined when a currency regime is chosen that achieves price and exchange rate stabilization at the cost of an increase in the country's foreign debt. Instead, countries need to develop the ability to generate foreign reserves by generating export 
surpluses. ${ }^{2}$ Such a strategy is helped by a tendency toward an undervaluation of the currency, as illustrated by the successful adopters of this development strategy such as West Germany in the 1950s and Japan in the 1960s and 1970s. The East Asian tiger economies - and then China - have very successfully followed this strategy more recently.

But developing sound fiscal and monetary institutions and generating export surpluses will not suffice to achieve key currency status. The literature on the determinants of key currency status points to another factor, namely the size of the economy. Matsuyama, Kiyotaki, and Matsui (1993) explain the international use of currencies and, succinctly, the determinants of key currency status as a function of relative country size and the degree of international economic integration. Because of network externalities and transaction costs, the global portfolio is concentrated in only a handful of currencies. In some ways money is comparable to language, whose usefulness is also dependent on the number of people with whom one can communicate; similarly a currency's utility rises with the number of other market participants using the same currency (Dowd and Greenaway 1993). A currency's attractiveness also increases with its transactional liquidity, which in turn is dependent on the existence of well-developed and broad domestic financial markets that offer a wide range of short and long-term investment opportunities in that currency, as well as fully operating secondary markets (Cohen 2000). Eichengreen, Hausmann, and Panizza (2005) point out that larger countries offer significant diversification possibilities, while smaller countries add fewer diversification benefits relative to the additional costs they imply.

As a result of these factors the global portfolio is concentrated in a small number of currencies (those at the top of the international currency pyramid) for reasons partly beyond the control of even those countries that follow sound domestic policies. Developing key

2 For example, the fact that the US has been running a current account deficit since 1982 (except for a small surplus 1991) has contributed to the worry about the long-term stability of the dollar an questions about its status as the world currency. 
currency status is hence a very difficult and perhaps even impossible endeavor for small economies. Eichengreen et al. (2005) show larger economies to have less of a problem borrowing in their own currency than do smaller economies. Using different measures of size, their estimates suggest that economic size is robustly and negatively correlated to "original sin," i.e., a situation where it is impossible for a country to borrow abroad in its domestic currency.

Taking into account these conditions, China certainly has the potential to elevate the RMB to key currency status. Assuming continuous economic and political stability in China (admittedly a significant assumption), China can be expected to replace the US as the world's largest economy in the foreseeable future, even if the country's growth rate slows significantly compared to the 10 percent annual average recorded over the past three decades. Although the People's Bank of China (PBOC, sometimes abbreviated PBC), China's central bank, is not institutionally independent, China's leadership is generally inflation averse and likely to continue to grant the PBOC sufficient operational independence to prevent high inflation, given that the latter could cause social unrest. ${ }^{3}$ Last but not least, China has been running significant current account surpluses, which have been driving appreciation expectations.

However, as many studies have highlighted, there are also conditions that China does not fulfill at the moment: In particular, China is currently lacking deep and liquid capital markets; the RMB is not fully convertible (i.e., it is not freely tradable in global currency markets); and the capital account is still tightly regulated (e.g., Prasad and Ye 2011, Volz 2013). Without a further opening of the capital account and convertibility of the RMB, the latter cannot assume a major international role besides being an invoicing country in (mostly regional) trade. Nonetheless, China's government could, in theory, implement the necessary

3 As shown by Bell and Feng (2013), the PBOC has been able to gradually but steadily increase its authority in the area of monetary and financial policy. 
policies fairly quickly, and with foreign portfolio capital inflows domestic Chinese capital markets would probably then see considerable growth. Moreover, taking into account the historical experience of the US dollar, which went from having no international role to being the leading international currency in less than a decade (Eichengreen 2011), we could indeed see the RMB rise to key currency status very quickly.

In practice, however, reform of the capital account and convertibility of the RMB are hotly contested issues in China. Moreover, these reforms necessarily are linked with reform of the domestic financial sector, since the capital account cannot be fully liberalized before the overhaul of the interest rate setting system, among others, is completed. The speed of reform is hence not yet decided. Before analyzing the preferences of different interests within China with respect to these issues, and what they imply for the reform process and hence RMB internationalization, the next section will briefly review the steps already taken toward capital account opening and RMB internationalization.

\section{China's evolving roadmap for RMB internationalization}

Since a number of recent studies, including Cohen (2012a), Prasad and Ye (2012), and Volz (2013), have reviewed the steps taken to liberalize China's capital account and promote the internationalization of the RMB, the following overview is kept very short. A summary of China's framework for capital controls is provided in Table 1. Major steps taken by the Chinese authorities toward RMB internationalization are listed in Table 2. Table 3 provides information on the 24 bilateral currency swap agreements that the PBOC had entered into with other central banks as of December 2013.

[Tables 1, 2 and 3 about here] 
Various initiatives have been announced and implemented over recent years to promote $\mathrm{RMB}$ internationalization, including a subnational pilot program on RMB crossborder trade settlement (later extended to the country as a whole; the issuance of sovereign RMB-denominated bonds and permission for the issuance of corporate bonds in Hong Kong and elsewhere; pilot programs for RMB-denominated outward foreign direct investment (FDI) for residents of 20 cities and provinces; and, most recently, the establishment of a special zone to experiment with direct currency convertibility in Shenzhen, the city that designated as China's first special economic zone and test-case for economic reforms in 1980.

However, as Table 1 demonstrates, China's capital account is still tightly regulated, with the exception of inward FDI. Direct investment inflows still need approval, but face less severe restrictions than portfolio inflows. Since 2002, licensed foreign investors, so-called "Qualified Foreign Institutional Investors" (QFII), have been granted permission to invest in China's capital markets, but they still face quota restrictions and are constrained to invest only in certain asset classes. Capital outflows, except for direct investments, are also tightly regulated or banned altogether. Although the goal of capital account liberalization was put forward in the $12^{\text {th }}$ Five-Year Plan outlining the policy for the years 2011-15, the authorities had not as of late 2013 provided details on how quick liberalization should proceed and how far it should go, even as the goal of capital account liberalization was reiterated at the CCP's Third Plenum in November 2013.

The discussion within China on capital account liberalization recently intensified, with the unveiling of a PBOC blueprint for an accelerated opening of China's financial sector. In a February 2012 interview to the "China Securities Journal," one of the country's most influential newspapers, a senior PBOC official outlined a three-step plan for liberalizing the 
capital account over the next ten years (Sheng 2012). ${ }^{4}$ According to this plan, the next three years would see a loosening of direct investment controls and a liberalization of capital flows out of China to take advantage of lower valuations for Western companies. Over the next three to five years, the plan also foresees deregulation of commercial credit controls and an increase in foreign RMB-denominated lending by Chinese banks to raise the RMB's global status. In the third step, within five to ten years, China would "gradually open up trading of real estate, stocks and bonds to foreign investors". By the end of the plan's third phase, China would have achieved a great (yet not clearly specified) degree of RMB convertibility.

Even though the PBOC's plan does not reflect the government's official position, it represented the first time any Chinese government body had proposed a concrete timeline for RMB internationalization. The draft plan thus boosted discussion about the costs and benefits of capital account liberalization and RMB internationalization, as well as the time horizon over which both should be achieved. The costs and benefits of RMB internationalization will be outlined in the following section, and complemented by an analysis of who is set to benefit, and who to lose, from capital account and domestic financial market liberalization, both of which are essential preconditions for turning the RMB into a truly global currency.

\section{The intertwined political economies of RMB internationalization, capital account liberalization, and domestic financial market reforms}

This section details the benefits of costs of RMB internationalization for the Chinese economy, then discusses the implications of related reforms of capital account opening and domestic financial deregulation, and the overall political economy of Chinese financial reforms across these various arenas. It concludes with a brief recap of the current reform policies.

4 The plan is based on an unpublished research project conducted by the PBOC's Statistics Department. 
Benefits and costs of RMB internationalization

From a Chinese perspective, there are several potential benefits of RMB internationalization. ${ }^{5}$ Besides the political prestige of issuing a global key currency, benefits for Chinese firms arise if they can use the domestic currency for international transactions, which means that they can shift exchange rate risk to their trading partners and hence need not hedge. ${ }^{6}$ Wider RMB use also would improve Chinese financial firms' international competitiveness. As the international use of the RMB expanded, international loans and investments increasingly would be executed through Chinese financial institutions, which would also help to boost Shanghai as a financial center (Gao and Yu 2011). Furthermore, China would earn additional seignorage through the international use of the RMB. ${ }^{7}$

There are, however, also costs of currency internationalization. First, greater international use of a currency implies that international demand for that currency will increase beyond what is needed for domestic uses, which will tend to drive up the currency's value, reducing export competitiveness. For this reason the German Bundesbank and the Bank of Japan both opposed larger international roles for the deutschmark and the yen, respectively. Given the constant stream of capital inflows into US financial markets over the past decades, which have generated pressure for dollar appreciation and eroded the competitiveness of US exports, Pettis (2011) referred to the dollar's special status as an exorbitant burden, a

5 For an overview of the costs and benefits of international currencies see, for instance, Cohen (1971, 2000, 2012b).

6 Chinese firms engaging in international trade did not face any exchange rate risk between 1994 and July 2005, when the RMB was pegged to the dollar at an exchange rate of 8.28 RMB to the dollar, or between July 2008 and June 2010, when China reinstalled a tight peg against the dollar in the face of the global financial crisis, at a rate of 6.8 RMB to the dollar. However, a freely-floating RMB would expose Chinese firms to currency risk if transactions are denominated in foreign currency.

7 According to estimates by Jefferson (1998), total seignorage earnings in the US may amount to as much as 3 percent of total annual tax revenue or 0.5 percent of GDP. Since the 1990s more than 50 percent of US dollars have circulated outside the US. 
refutation of Valéry Giscard d'Estaing's famous characterization of the dollar's special role as a "privilège exorbitant."

For China, full RMB internationalization eventually would also imply an end to the dollar link, which likely (although not necessarily) would result in significant appreciation against the US dollar. Chinese export industries, supported by the powerful National Development and Reform Commission (NDRC), the macroeconomic management agency under the State Council, and the Ministry of Commerce, have long been trying to prevent this from happening. ${ }^{8}$

Second, a currency's greater international use to some degree compromises monetary policy independence, as it makes more difficult for the central bank to control the domestic money supply. The German and Japanese monetary authorities, for instance, tried to increase their influence over the money supply by imposing controls on capital flows in the 1970s and into the 1980s (Tavlas 1991: 36-37; Schobert and Yu forthcoming). In the US, former Federal Reserve Chairman Alan Greenspan repeatedly complained that the steady inflow of capital into US financial markets made it impossible for the Fed to raise long-term bond yields.

In the case of China the situation looks a bit different, since China's monetary policy autonomy already has been compromised by the current link to the US dollar (Reade and Volz 2012). While employing capital controls and relying on instruments other than the interest rate have granted the PBOC leeway to exert relatively autonomous monetary policy, the current arrangement has serious costs. In particular, the PBOC has been constrained in its ability to use interest rate policy effectively. It must keep interest rates low to avoid attracting capital inflows, which would put upward pressure on the country's exchange rate and require the PBOC to intervene in the foreign exchange market and sterilize these interventions through open market operations. It is hence understandable that the PBOC has been seeking to 
push reform of the exchange rate regime with a view to strengthening of the monetary policy transmission mechanism and overcoming the need to continuously accumulate dollar reserves - which comes at great cost for the Chinese economy. On a more general level, RMB internationalization can be thus seen a means to overcome the dependency on the US dollar.

Keeping nominal interest rates low has led to negative real interest rates for deposits. The average annual real return on one-year deposits in Chinese banks has been negative since 2003, in contrast to an average annual real return of 3 percent over the period 1997-2003 (Lardy 2012a). These negative real deposit rates are an implicit "financial repression tax imposed on Chinese households" (Pettis 2012: 9), since they reduce households' income from their financial investments. Besides depressing household income, low interest rates have arguably contributed to the build-up of the country's property bubble, by causing a much larger allocation of investment into real estate, where real returns on property investment have been much higher than those on bank deposits. The prevailing exchange rate system has thus contributed to serious distortions in capital allocation and exacerbated macroeconomic imbalances of the Chinese economy (Lardy 2012a; Ito and Volz 2013). Hence, reforms related to RMB internationalization addressing these problems would yield benefits in terms of macroeconomic rebalancing and improved financial stability.

\section{Winners and losers from capital account opening and domestic financial liberalization}

Since exchange rate and capital account reform have ramifications for domestic interest rate liberalization and hence for reform of China's financial sector at large, the discussion on RMB internationalization has to be seen in the context of the interests of the different stakeholders that will be affected by such reforms. As is often the case with reforms, financial market reform in China will produce both winners and losers. Many interests benefit from the status quo and thus tend to oppose either RMB internationalization per se, or other 
policy shifts such as domestic financial liberalization which are logically linked to RMB internationalization. These typically anti-reform constituencies include large state banks, state-owned industrial enterprises, the NDRC, and the Ministry of Finance.

For Chinese banks - which are primarily state-owned and enjoy oligopolistic rents the negative real deposit rates have been like subsidies. With a ceiling on deposit rates and a floor on lending rates, banks have gotten used to living with a "comfortable margin of around 3 percent" (Borst 2012a). According to Borst (2012a), "Xiao Gang, the chairman of the Bank of China, estimated in 2010 that the non-liberalized interest rate regime in China gave banks a net interest spread twice as large as that for foreign currency loans in the international market." With interest income accounting for 80 percent of bank income in 2011, Borst (2012a) points out that "a narrowing of the interest rate spread has serious implications for bank profitability." It is hence not surprising that the major banks have been strongly opposing interest rate reform - which would be unavoidable if the capital account were to be opened. In April 2012, then Premier Wen Jiabao, generally considered a champion of the proreform faction in government, openly criticised the "monopoly" profits of state-owned banks and called for a shake-up of the current system. The four biggest state-owned banks, which dominate the banking system, had an average return on equity of about 26 percent in 2011 (cf. WSJ 2012: C24). They would be clear losers of financial market reform. Not only would the banking sector have to forego the negative real deposit rate subsidy it currently enjoys. Capital account opening would also open the Chinese financial sector to outside competition and erode the profits banks were able to extract in a hitherto oligopolistic (state-owned) system.

Low interest rates have also benefited state-owned enterprises (SOEs), which have enjoyed monopoly privileges in many sectors, and which also have received cheap funding from the state-owned banking system. According to Unirule (2011), a Chinese think tank, 
"easy access to bank loans at a third of the market rate" (cf. Breslin 2012a: 37-38) has been one of the reasons behind the relatively high profitability of SOEs. ${ }^{9}$ Like the banks, the SOEs strongly oppose financial market reform as they would have to cede to rely on cheap (and essentially subsidized) finance and face increasing competition from the private sector. While competition would benefit overall welfare, the SOEs would be hurt. It should be noted that in the Communist Party hierarchy top executives of large SOEs routinely wield as much power as the government ministers who formally supervise them. Their strong opposition to domestic financial liberalization has therefore been a significant blockage to reform.

Interest rate liberalization and a lifting of the restrictions on capital outflows would also hurt the real estate and construction industries, which have profited from the negative real deposit rates and a lack of alternative investment opportunities that have made residential property a preferred asset class (so much that this has led to a property bubble).

Moving toward a more market-based financial system would also require the government (and the CCP) to give up much of its influence over the domestic banking system, which thus far has been one of its most powerful tools in steering the economy (and which is also increasingly used to enlarge Chinese influence abroad, as will be discussed later). As Breslin (2012a: 36) points out, the state's control over the financial sector has been central to remaining at the "commanding heights" of the economy.

Finally, financial market reform would also have far-reaching and in the short run adverse implications for public finances. As pointed out by Shih (2012), the central government is directly or indirectly the largest debtor of the financial system. Interest rate liberalization, which would drive up deposit and lending rates, would significantly raise the government's borrowing costs. Shih estimates that every basis point increase of the interest

9 Other factors are subsidised rent on land, lower tax rates than for private corporations, and tax breaks on energy. 
rate imposes an additional RMB6.9 billion of interest payments on state-owned debtors. Moreover, market-based interest rates may also threaten the survival of numerous SOEs, which would create additional costs for the government.

On the winning side of financial liberalization would be households, who would be freed of the current financial repression tax. Lardy (2012a) estimates that interest rate liberalization would boost household income by two percent. ${ }^{10}$ In addition, abolishing the cap on deposit rates and increasing bank competition would improve small and medium enterprises' access to credit. While the current lending rates are low, these benefit SOEs, while small and medium private enterprises are typically excluded from credit, and have been forced either to rely on internal earnings or seek credit in the shadow banking sector. Marketbased interest rates would help alleviate this problem and reduce the power of SOEs over the economy. The majority of the Chinese private sector therefore supports market-oriented financial reform since they can expect improved access to credit. Indeed, small and medium private enterprises have called for speeding up reforms, but generally speaking lack political clout. Finally, there have been also calls from private Chinese investors, frustrated with the limited range of investable assets in China, to allow capital outflows.

Vested interests and the political economy of financial reforms

The pro-reform constituencies have had a strong ally in the central bank, the PBOC, whose officials believe that financial liberalization is necessary to rebalance the economy and improve the functioning of the economy at large. Moreover, it is clear that interest rate reform

10 This would also help boost the household consumption rate, which in turn is an important condition for rebalancing the economy and reducing its export dependency (cf. Ito and Volz 2013). As Lardy (2012b) explains: "Negative real deposit rates have had a double-barrelled adverse effect on private consumption expenditures. First, negative rates have depressed the growth of household income, leading to lower consumption. Second, in response to sustained negative real deposit rates, households have sharply increased the share of their after-tax income that goes to savings, further depressing the share of private consumption expenditure in China's GDP." 
- as well as exchange rate reform - would further increase the PBOC's authority and control over banking and macroeconomic policy. The PBOC has, over a long period, made great efforts to reform the conduct of monetary policy and push interest rate liberalization, moving in the direction of more market-determined interest rates, designed to improve the allocation of credit and improve the transmission mechanism of monetary policy. Yet the shift toward the use of more price-based mechanisms has been impeded by the PBOC's lack of independence. Indeed, much of the influence over Chinese monetary policy rests with the NDRC, which dominates decisions over macroeconomic policy, and the Central Leading Group on Finance and Economic Affairs (CLGFEA), the "advisory and co-ordinating agency of the CCP's Politburo in managing economic affairs, and a core leading and decision-making body for the Chinese economy" (Bell and Feng 2013: 50). The NDRC, which "has been a major power contender against the $\mathrm{PB}[\mathrm{O}] \mathrm{C}$ in the finance sector [already] in the reform era", has "fought hard to maintain its formidable but narrow power in the financial sector" (Bell and Feng 2013: 51). The NDRC strongly has favored quantitative measures aimed at steering the amount, rather than the price, of credit, thus effectively preventing the PBOC from using its entire monetary toolkit. The NDRC, which is responsible for SOEs as the "quasi-central planning" agency under the State Council and assumed to care more about economic growth than inflation, has been very reluctant to move forward with domestic financial market reform.

Another direct challenger to the PBOC's pro-financial liberalization position has been the Ministry of Finance (MOF), with which the PBOC has fought a "turf war" over authority over financial reform since 2003 (Bell and Feng 2013). Until the present, the MOF has retained control of the "Big Four" state-owned commercial banks (Bank of China, China Construction Bank, Industrial and Commercial Bank of China, and Agricultural Bank of China) through its control over Central Huijin Investment Ltd., a state-owned investment company established in 2003. 
Even though most economists (including those within China) would agree that financial market reform is needed and that it would benefit the overall economy, expert opinion differs as to the urgency and ideal sequencing of reforms. Moreover, reforms are hampered by the vested interests of the beneficiaries of the current system. As Huang (2012) observes, "policymaking is not as unified as it seems to the amateur observer", and "[r]esponsibilities are compartmentalised under different senior leaders and "leading groups" and therefore they are vulnerable to capture by vested interests."

The NDRC and other branches of government that are hesitant to move ahead with financial market reform and capital account opening regularly point to the dangers that capital account opening can bring for financial stability. Indeed, a fast liberalization of the capital account entails the risk of financial crisis, as seen by the crises experienced in countries like South Korea and Mexico shortly after financial opening. It is particularly risky to open too fast without having a sound domestic financial sector and a well-developed capital market as is the case in present China. Since financial and economic crisis could cause social unrest and political instability, and threaten the survival of the current political system, it is unlikely that the reformers will be able to go forth with a swift liberalization and economic reform.

Against this backdrop, coming forward with the above-mentioned three-step plan for liberalizing the capital account over the next decade can be seen as an affirmation by the PBOC of the irreversible goal of RMB internationalization in response to recent increasing domestic doubts and debates (Gao and Volz 2012). It also transmits the message that the strategic time for China to open up its capital account is now, and that the risks of opening are controllable. The PBOC downplays the risks of opening the capital account and argues that the need to establish preconditions such as domestic interest rate marketization, the introduction of greater exchange rate flexibility, and similar policies before capital account opening should not be over-emphasized. Specifically, the PBOC has highlighted four reasons 
why the potential risks of financial opening are small (cf. Gao 2012): (1) the risk of currency mismatches is limited since both the assets and the liabilities of Chinese commercial banks are mainly denominated in domestic currency; (2) Chinese foreign reserves are mainly invested in bond markets, so that market fluctuations have minimal impact on revenues; (3) short-term foreign liabilities account for a small portion of China's overall foreign debt; and (4) domestic property and asset price developments are under control.

There is no doubt that PBOC is aware of the risks of current account opening. Hence, one can safely assume that it does not actually expect the proposed reforms to proceed within its suggested time frame, in the context of determined resistance from the anti- reform camp. Given the public's benign view on RMB internationalization as a reflection of China's growing statue in the world, the current debate on RMB internationalization may be understood as an attempt of the PBOC to push for domestic financial market reform - which is the precondition for current account opening - and also for a reform of monetary and exchange rate policy (Gao and Volz 2012). ${ }^{11}$ Some would even argue that PBOC Governor Zhou Xiaochuan "conned" CCP leaders when he convinced them "in 2009 to try to make the yuan an international standard" by using "the language of economic nationalism to push an agenda that ultimately would loosen state control of the economy by making the yuan $[\ldots]$ more dependent on market forces than government orders" (Davies 2011). Davies (2011): referred to this approach as "a Trojan horse strategy: Make the policy arguments so attractive that decision makers will approve the ideas without realizing the implications - like the Trojans accepting that beautiful horse from the Greeks without realizing what was inside."

The PBOC's announced tentative three-stage liberalization plan thus may have been in the nature of a trial balloon to test for public sentiment on this matter - with the Chinese public's responses including both applause and anger. As noted by Gao (2012: 10-11),

11 On the sequencing of reforms, see Yu (2012). 
immediately after the PBOC publicized its three-stage plan, "an instant critique appeared in both Chinese and overseas media," with some pundits comparing the proposed current account liberalization to an "opening of the floodgate" and inviting foreign "wolves" into the Chinese "sheep's house." Reformers utilize the RMB internationalization discussion as a means of fostering financial sector reform, similar to the way that the earlier goal of China's entry into the World Trade Organisation (WTO) was used to push through far-reaching economic reforms in the late 1990s. ${ }^{12}$ This discourse is still ongoing, and the speed at which the reforms will move ahead is not yet determined. To overcome opposition to reforms, the new Chinese leadership will have to show "political courage to deal with vested interests" and the willingness "to cushion the cost of change for those who will lose out in the reform process" (Huang 2012).

However, sooner or later policymakers will need to enact some type of financial reform. The problems associated with the current financial repression are building up, and the case for financial market reforms, especially interest rate reform, is becoming ever stronger. The negative real interest rates offered on deposits have led investors to consider alternative financial investments. ${ }^{13}$ Increasingly, banks have to compete for funds by offering so-called “wealth management products," which are short-term savings instruments with yields higher than the regulated deposit rates. While wealth management products offer choices for more

12 According to Chow (2003), “[t]he main motivation of Premier Zhu Rongji in promoting China's entry into WTO was to use foreign competition to speed up economic reform in both the industrial and service sectors", where reforms had slowed down in the late 1990s "because of the inertia coming from vested interests of a group of formerly appointed managers holding on their positions". On reforms in the agricultural and financial sector ahead of China's WTO entry see Lin (2000).

13 As a recent article in the Financial Times put it, “[p]ublic anger is mounting at the banks' huge profits and their monopolistic power. It is not quite Occupy Jinrongjie (Financial Street) in Beijing, but regulators are finding themselves on the back foot as they try to defend banks. [...] Industrial and Commercial Bank of China, the country's largest bank, has recorded average profit growth of 35 per cent over the past five years. [...] China has been spared the expense of a direct bailout, but the rules that cap deposit rates and limit bank competition add up to a large hidden tax on savers. [...] More worrying for China's mollycoddled banks is that popular frustration is beginning to turn into action that could hurt them: not complaints or protests, but withdrawal of money. Savers are depositing cash outside traditional bank accounts in a growing array of "wealth management products". These offer savers higher deposit rates, forcing banks to compete on interest rates, eroding margins and denting profits. While far from a crisis yet, it is an alarming trend for banks. Public anger, not pure economics, might be the undoing of the Chinese banking model." (Rabinovitch 2012: 20) 
affluent investors and reduce the profit margins of banks - which in the view of some "amounts to a de-facto liberalisation of interest rates" (The Economist 2012) - the proliferation of such structured and largely unregulated investment vehicles also leads to a build-up of risk in the (shadow) financial system.

Furthermore, financial repression and the constrained access to formal credit for small and medium enterprises has caused the informal financial sector to mushroom. By some accounts, at least one-quarter of all financial transactions are now carried out in the informal financial sector (Ayyagari et al. 2010). A 2013 report by the Chinese Academy of Social Sciences put the size of the shadow banking sector (comprising all shadow-lending activities including wealth-management products, trusts to interbank business, finance leasing and private lending) at RMB20.5 trillion (\$3.35 trillion) at the end of 2012, the equivalent of 40 percent of GDP, although foreign banks and rating agencies have come up with much larger estimates (Zhu 2013). According to Allen et al. (2005), credit created outside formal banklending through alternative financing channels - including through informal financial intermediaries, internal financing, trade credit, and alliances of various forms between firms, investors and local governments - has been crucial for supporting the growth of the Chinese economy. However, the growth of shadow finance, which also includes loans arranged by banks but not recorded in their books, has created considerable risks for financial stability. To reign in these risks and prevent a further uncontrolled development of the informal and shadow financial sector, financial reform is crucial.

\section{Recent advancements with reforms}

Despite the difficult political economy of reform just detailed, progressives have continued to push for reforms, and modest progress has been recently made in some areas. For instance, in June 2012 the PBOC granted banks more flexibility in setting deposit and lending 
rates: while banks hitherto had no room at all to deviate from the official benchmark deposit rate and lending rates were only allowed to be 10 percent below the benchmark lending rate at most, the new rules for setting interest rates allowed banks to offer interest rates to depositors that are 10 percent higher than the benchmark deposit rate and make loans at 80 percent of the benchmark lending rate. A month later the limit on lending rates was further reduced to 70 percent of the benchmark rate set by the PBOC. But even if this liberalization was a move in the right direction, it introduced only little flexibility to the interest rate setting system.

In July 2013 the PBOC made further advancements in reforms when it announced to remove the floor on lending rates and allow financial institutions to price loans by themselves, which is a significant step towards interest rate liberalization. China's domestically-traded banking shares fell sharply the first trading day after the PBOC made this announcement, reflecting the expectation that interest rate reform will hurt the bank's profitability (WSJ 2013). ${ }^{14}$ However, the PBOC did not remove the ceiling on deposit rates, which arguably is the most binding interest rate control (Feyzioğlu et al. 2009). Relaxing controls on deposit rates will have much more significant effects on the profitability of banks and the wider economy. How long it takes for interest rate liberalization to be completed remains to be seen.

An experiment that has generated huge interest and fuelled the hopes of reformers is the financial liberalization pilot program in the city of Wenzhou, which was approved by the State Council in March 2012. ${ }^{15}$ Under this program, private lenders - which had been operating informally before - are allowed to operate loan companies and provide credit to small and medium-sized enterprises. Moreover, the State Council is considering to allow residents of Wenzhou to invest up to $\$ 200$ million abroad, with a maximum of $\$ 3$ million per resident. If these reforms get implemented, Wenzhou could indeed become a test ground for financial reforms for all of China. 
But whether and at what speed market-oriented interest rate reform and particularly capital account opening will proceed, remains an open question. The Chinese government is risk-averse, and there is no domestic political pressure to liberalize the capital account soon especially not at times of a volatile world economy and excessive global liquidity seeking returns in emerging economies (Volz 2012). Since RMB internationalization without a clear sequencing strategy could cause trouble for China's banking system, capital account liberalization can be expected to proceed very gradually - probably at a pace that is much slower than the PBOC plan would suggest. This is particularly true in the face of fierce opposition to reforms from the beneficiaries of the current system, which have "acquired disproportionate influence over economic policy" and which to date "have been able to block much-needed policy reforms" (Lardy 2012b).

Given that financial repression and regulated interest rates are "at the heart of the Chinese financial machine" (Sender 2012: 22) and a key element to the CCP's influence over the Chinese economy, financial reform is hardly a minor technical change to the current system, but rather a very far-reaching structural policy shift and a major regime change. But as Pettis (2013: 3) points out, it is not clear yet whether the Party leadership has developed the "political will to face down opposition to any change in a growth model that has been extremely profitable for some very powerful sectors within the economy." As Davies and Wei (2013) put it, standing in the way of reform are "many of the biggest beneficiaries of China's past growth model". Even Premier Li Keqiang acknowledged the problem of vested interest blocking reforms at his inaugural press conference, where he reportedly said that "[s]ometimes, stirring vested interests may be more difficult than stirring the soul" (Economist 2013).

After completion of the "Third Plenary Session of the $18^{\text {th }}$ CCP Central Committee" in November 2013, the new administration of President Xi Jinping published a blueprint for 
economic and social reforms, comprising 60 points which are to be implemented by the year 2020. The plan emphasizes that "[e]conomic structural reform is the focus of deepening reform" and that the Chinese leadership will "ensur[e] that the market has a decisive function in resource allocation" (CCP 2013, (3)). In the document the Party also vows to "vigorously and reliably move marketization reform forward in breadth and depth, substantially reduce direct government allocation of resources, promote that resource allocation is based on market principles, market prices and market competition, to realize productivity maximization and efficiency optimization" (ibid.). Relating to financial market reforms, the leadership reiterated its commitment to "[e]xpand domestic and international financial openness, under the precondition of strengthening supervision and management", create "[p]erfect mechanisms for the formation of Renminbi exchange marketization", "accelerate with moving interest rate marketization forward", “[p]romote bidirectional openness for capital markets, raise the extent of convertibility of cross-border capital and financial trading, establish and complete foreign debt and capital flow management systems under prudential macro-level management frameworks, [and] accelerate the realization of the convertibility of Renminbi capital accounts" (CCP 2013, (12)). The state media (unsurprisingly) lauded the outcome of the Third Plenary, with the People's Daily (2013) remarking that "with the reform blueprint in place, the key now is to put that blueprint into reality step-by-step".

Thus, it appears that, at least rhetorically, President Xi's administration is committed to sweeping economic reform, including financial liberalization. However, this was also true for President Hu's administration, whose reform record is widely seen as disappointing. Possibly the most significant decision taken at the Third Plenum was to set up a "Leading Small Group on Comprehensively Deepening Economic Reform" to manage the economic transformation and coordinate the work of powerful ministries and commissions (Anderlini 2013). This new body, which will concentrate power over the economy directly under President Xi's control, may indeed increase the chance that reforms will progress in the 
direction indicated at the Plenum and that they will be completed as planned by 2020. Yet success is not given. As Moses (2013) points out: "China's reformers are still plodding along a very tough track. The path they've laid out is laudable, but it's still far from certain that they will be able to navigate it to the end."

\section{China's international ambitions and the diversity of its financial statecraft}

This chapter primarily has focused on the domestic political economy of Chinese financial policymaking. Does this imply, then, that decisions on international financial choices such as currency internationalization and capital account liberalization are really not foreign economic policies at all? No. As discussed, the notion of developing the RMB into a major - and in the longer run perhaps the major - international currency, resonates well with the Chinese public and the political leadership. Elevating the RMB to a prominent status in the world economy that can rival the dollar is part and parcel of an ambitious vision to reposition China as the leading economic power, not only in Asia, but in the world economy. Although this vision is not framed as an official foreign policy goal, it is backed by the belief, widely held by policy elites as well as the general public, that China is now leaving behind a century of humiliation and regaining its deserved role in the world. Policymakers harken back to China's golden era of wealth and power before it fell prey to imperial subjugation from the late $19^{\text {th }}$ century onwards. A leading international role for the RMB resonates well with "the Chinese Dream of the great rejuvenation of the Chinese Nation" (CCP 2013).

Given the growing strength of China's economy and the swelling of China's foreign exchange reserves over the past decade, FS has been a powerful way for China to extend its stature in the regional and global economy. Besides the steps taken toward RMB internationalization, Chinese leaders have verbally criticized "reckless" fiscal and monetary policy on the part of the US, which China accuses of destabilizing the global monetary 
system. China's international FS also includes contributions to regional financial and monetary cooperation (see this volume's contribution by Katada and Sohn), granting of credit and aid to foreign entities through the state-owned financial system, and the country's engagement with international fora such as the G20 and BRICS.

But despite its potential, it appears that China thus far has lacked a coherent strategy of international FS, as it often responds to outside developments rather than attempting to actively shape the international agenda. In other words, China's FS often appears defensive and reactive, rather than offensive and creative. Its role in regional financial and monetary cooperation in East Asia is a case in point. Although China, now the largest Asian economy, aims to be a regional leader, it has been hesitant to fill this leadership position. Most of its moves toward greater regional financial and monetary cooperation have come as a response to initiatives from other East Asian countries, especially Japan, whose government has sought to position Japan as the leading economic power in the region. Both countries appear to be involved in a strategic game for regional leadership that has developed into a "competition for regional cooperation" (Volz and Fujimura 2009; Volz 2010).

Examples of Japan-China competition spurring the Chinese government to greater initiative in the international financial sphere are not difficult to discover. For instance, the Chinese government at first responded negatively to the Japanese proposal in 1997 to create an Asian Monetary Fund. Yet only two years later, it was the Chinese foreign minister who called on the ASEAN+3 Finance Ministers to establish a framework for regional financial cooperation, which then resulted in the launch of the Chiang Mai Initiative (CMI) in 2000. But even after its establishment, China has been hesitant to support bold moves to develop the CMI into a full-fledged regional monetary fund and was seen as responding to proposals by the other ASEAN+3 nations rather than actively setting the agenda. In particular, China has been reluctant to increase its financial contributions and also to de-link disbursement under 
the CMI (or CMIM, as it has been called since it was "multilateralized" in 2010) from the International Monetary Fund (IMF). Apparently Chinese leaders have been worried about the risk of moral hazard, whereby countries would be encouraged to be less prudent than they otherwise would be, knowing that the regional fund was available to bail them out. ${ }^{16}$ China has thereby missed an opportunity to show leadership in strengthening the regional financial architecture. $^{17}$

A similarly careful and defensive pattern of financial policymaking has been apparent on the global, multilateral stage, where China has been very cautious about committing itself to binding agreements or new financial contributions. China's response to the global financial crisis of 2008-09 provides an illustration. While China was quick to announce a huge, RMB 4 trillion fiscal stimulus package in November 2008 to boost domestic demand and counter a slump in global demand for its exports - a policy that won the Chinese government international praise - the Chinese leadership was slower than many other G20 members to follow up on the agreement reached at their London G20 Summit in April 2009 to contribute to a tripling of the IMF's lending capacity to $\$ 750$ billion. In contrast to Japan, the first country to heed the chance to sign a $\$ 100$ billion lending agreement with the Fund in February 2009 (almost two months prior to the G20 Summit) and thereby show its readiness to assume international responsibility, the Chinese leadership waited until June to signal its intention to invest up to $\$ 50$ billion in notes issued by the IMF (the final agreement was signed in September 2009). ${ }^{18}$ Although this was the third-largest contribution by an individual country (after the $\$ 100$ billion each pledged by Japan and the US, respectively), it came too late to be perceived as leadership. Of course, Chinese policymakers rightly point out that China still has a relatively low per capita income, but given that the country has by far the

16 The fear of moral hazard is shared by Japan, the other big contributor to the CMIM.

17 The development of regional financing arrangements has also been a means for emerging economies to demand a greater say in the governance of the IMF. See McKay et al. (2011).

18 Cf. IMF (2012). 
world's largest foreign exchange holdings (which are largely invested at very low or even negative returns in US treasuries), and that lending money to the IMF is virtually risk-free, the opportunity cost of stepping up to the plate and announcing a big contribution to IMF finances early on in the crisis would have been zero, whereas the political gains would have been large. Of course one may argue that China's hesitation to engage in or contribute to the multilateral system is due to its under-representation in the governance structure of international financial institutions like the IMF and the World Bank. But if anything, increasing its contributions would strengthen China's demand for a greater say in these institutions.

One international forum in which China has acted with relative ease is the BRICS, where China has joined Brazil, Russia, India, and more recently South Africa, in criticizing both the fiscal and monetary policies of the United States since 2010, and in exerting collective pressure on its fellow members of the IMF and World Bank to expand the voting rights allocated to the BRICS as well as other large developing countries (e.g., Armijo and Roberts forthcoming). Within the BRICS, China has agreed to commit $\$ 41$ billion of its foreign exchange reserves to a Contingent Reserve Arrangement (CRA), a \$100 billion currency reserve pool to which Brazil, India, and Russia have pledged $\$ 18$ billion each and South Africa \$5 billion. However, as with the CMIM, China seems to insist on linking the CRA to IMF conditionality - another hint that China, which is set to become the third largest member country in the IMF, does not seek a complete remake of the existing international financial system (and supplant institutions like the IMF where it has increasing sway).

China's reluctance to engage more in the multilateral financial system may be due at least in part to a widely-held view among Chinese scholars and policy makers that "Western attempts to enlist greater Chinese involvement in global management and governance is a dangerous trap aimed at tying China down, burning up its resources, and retarding its growth" (Shambaugh 2011: 13). But as Katada and Sohn (2012: 19) point out, despite apparent 
suspicion and skepticism regarding global governance in Chinese policy circles, policy makers believe that China must involve itself in regional and multilateral cooperation at least to a certain extent, since they don't wish to tarnish China's international image "by behaving like a free-rider on the international system." There seems to be an uneasy relationship between the desire to be seen as a great power, and the responsibilities that being a great power might carry with it. As Breslin (2012b: 1) remarks, "[i]t seems rather clear that China wants to change its role in global politics, and also to change some of the ways in which the global order is governed", but it is "less clear [...] how this should come about and with what conclusions".

In general, China has been much more at ease when acting unilaterally, and here it has made the greatest efforts to use its economic and financial power abroad. In particular, besides entering bilateral central bank swap agreements, as mentioned above, China has been actively using its state-owned financial system not only to grant credit to domestic (mostly state-owned) firms investing abroad, but also to fund foreign activities, using its financial leverage as a means of foreign diplomacy and a way to secure the country's strategic interest in gaining access to natural resources or strengthening its commercial ties with other countries. In many cases, Chinese firms and banks have been able to offer comprehensive and financially very competitive packages to foreign governments, for instance in the area of infrastructure financing. ${ }^{19}$ Such financing, often in the form of foreign aid, has repeatedly been provided to develop infrastructure in resource-rich countries, helping to expand China's access to energy and other natural resources (Weston et al. 2011). ${ }^{20}$ In the framework of this volume, such use of financial and monetary levers to win friends, prestige, and influence abroad clearly is a form of offensive and bilateral FS.

19 Through public backing, China has emerged as a major financer of infrastructure projects in Asia, Latin America, and Africa (e.g., World Bank 2008).

20 By pursuing its interest largely outside the multilateral framework China has repeatedly received criticism for undermining international standards, such as those set by the members of the OECD Development Assistance Committee for the conduct of their development cooperation programs. 
Summing up, China has been actively trying to employ its financial power overseas, but this has mostly happened unilaterally. It typically has been reluctant to engage in regional or global initiatives. Given that a comprehensive reform of the international financial and monetary system - negotiated in a new Bretton Woods-type conference - is very unlikely, the unilateral approach that has dominated Chinese policies thus far may not appear to be the worst strategy, since benefits may accrue more directly. But although investments in strengthening the regional and global financial architecture may be more costly and not yield the same immediate returns as unilateral (or bilateral) initiatives, in the long run a solid multilateral financial architecture would be in China's best interest, given that China has a lot to gain from a stable global economy - and conversely a lot to lose from international financial and monetary instability. Moreover, a stronger commitment to multilateral cooperation would also help to build trust in the Chinese leadership - and trust is certainly needed to develop the RMB into a truly international currency.

\section{Conclusions and outlook}

Eichengreen (2011) recently observed that the US dollar went from having no international role to being the leading international currency in less than a decade. Similarly, the RMB could be very quickly accepted as a major currency for invoicing and settling trade, as a currency for undertaking financial transactions and investments, and as a major reserve currency for central banks. Whether and when the RMB will become a global lead currency depends to a large extent on economic and political stability in China and on the ability of China's leadership to reform the domestic financial system so that it can stand international competition after financial opening. As argued above, in the face of strong opposition from various special interests and rivaling party lines as well as the risks to overall economic stability from (badly managed) financial opening, rapid liberalization of China's capital 
account and the domestic financial system is unlikely. However, a strategy of gradual opening is quite likely so that the RMB can be expected to further gain in international importance not only as an invoicing currency for trade, but also for financial transactions. Government-led initiatives, such as arrangements with other central banks, will support this process, but will not be the deciding factor.

What have we learned about FS? One lesson from this chapter's case study of RMB internationalization is that what may appear to the outside world as a rather assertive, offensive, and systemic use of a country's financial capabilities - such as the not infrequent announcements on the part of some Chinese financial officials that their plan is to promote the increased global use of the RMB, displacing the US dollar - may have additional layers of meaning within a country's domestic political economy. Thus one may understand many Chinese domestic political battles around the goal of currency internationalization to be disguised disagreements over the pace of other domestic economic reforms - rather than struggles over Chinese foreign policy. Hence at present, the Chinese "challenge" to the existing global currency hierarchy through the RMB internationalization comes largely from the Chinese reformers' desire to restructure the country's rigid and inefficient financial sector.

In the short to medium-run, then, we may expect Chinese FS to continue to focus on bilateral and offensive initiatives - such as foreign aid tied to natural resource contracts, or bilateral currency swap arrangements - or on systemic FS, ranging from participation in regional currency arrangements to joining with other large emerging economies in such fora as the BRICS to lobby for greater clout in the international financial institutions.

In the medium to long-run, however, China's options for employing its national financial capabilities for a wide variety of foreign policy goals, political as well as economic, are much wider than those of any other emerging power. Among the BRICS countries, for example, only China has a realistic possibility of providing a major global reserve and 
investment currency sometime in the future. Yet this chapter has shown why that future will not arrive any time soon.

Nevertheless, RMB internationalization is progressing, and there are already signs that the RMB is becoming a regional lead currency in East Asia (Fratzscher and Mehl forthcoming; Subramanian and Kessler 2012). Given the great importance of the Chinese economy and its central role in the East Asian trade production network, other countries in the region are now cautiously managing their exchange rates vis-à-vis the RMB, and one can safely assume that it will continue to play a central role in the evolving regional monetary cooperation of East Asian countries (Volz 2010, forthcoming). Interestingly, it should be noted that the RMB can play this regional role without complete opening of China's capital account. For the RMB to become a serious alternative to the dollar on the global stage, in contrast, a full liberalization of China's capital account will be required. But this would imply that the Chinese government would have to relinquish control over much of its financial system and economy, something the government is not at present prepared to do.

Finally, whether or not the RMB can displace the US dollar as the world's major currency also will depend in no small part on US policies for maintaining the internal and external value of the dollar and keeping US financial markets attractive for international investors. In this respect, the incapacity of the US political system to put the country's fiscal system on a sustainable path, and the resulting recurrent threat of debt default, certainly do not help to increase the dollar's attractiveness. The future role of the euro and European financial markets, in turn, will depend on European countries' willingness to further integrate their economies and financial systems. The most likely scenario over the next two decades is the emergence of a multi-polar international monetary system, with the US dollar, the euro, and the RMB in the lead roles and smaller regional lead currencies in Africa, Latin America, the Middle East, and Central Asia in the second tier. 


\section{REFERENCES}

Allen, Franklin, Jun Qian and Meijun Qian (2005): "Law, Finance, and Economic Growth in China”, Journal of Financial Economics 77 (1), pp. 57-116.

Allen, Franklin, Jun Qian, Chenying Zhang and Mengxin Zhao (2012): “China's Financial System: Opportunities and Challenges”, in Joseph Fan and Randall Morck (eds.): Capitalizing China, University of Chicago Press, Chicago, IL, http://www.nber.org/chapters/c12071.pdf

Anderlini, Jamil (2013): “China: The Road to Reform”, Financial Times, November 13. Armijo, Leslie Elliott and Cynthia A. Roberts (forthcoming): “The Emerging Powers and Global Governance: Why the BRICS Matter", in Robert Looney (ed.): Handbook of Emerging Economies, Routledge, New York.

Ayyagari, Meghana, Asli Demirgüç-Kunt and Vojislav Maksimovic (2010): "Formal Versus Informal Finance: Evidence from China”, The Review of Financial Studies, Vol. 23 (8), pp. 3048-3097.

Bell, Stephen and Hui Feng (2013): The Rise of the People's Bank of China, Harvard University Press, Cambridge, MA.

Borst, Nicholas (2012a): “Are Chinese Banks Too Profitable?”, China Economic Watch, Peterson Institute of International Economics, March 29, http://www.piie.com/blogs/china/?p=1191

Borst, Nicholas (2012b): “Wen Jiabao Has the Wrong Solution for China's Banks”, China Economic Watch, Peterson Institute of International Economics, April 4, http://www.piie.com/blogs/china/?p=1237

Breslin, Shaun (2012a): "Government-Industry Relations in China: A Review of the Art of the State", in: Andrew Walter and Xiaoke Zhang (eds.) East Asian Capitalism. Diversity, Continuity, and Change, Oxford University Press, Oxford, pp. 29-45.

Breslin, Shaun (2012b): “China as Rising Power”, forthcoming in International Affairs. 
Burstein, Daniel (1988): Yen! Japan's New Financial Empire and its Threat to America, Simon and Schuster, New York.

CCP (2013): “CCP Central Committee Resolution concerning Some Major Issues in Comprehensively Deepening Reform”, Passed at the 3rd Plenum of the 18th Central Committee of the Chinese Communist Party on 12 November 2013, http://chinacopyrightandmedia.wordpress.com/2013/11/15/ccp-central-committeeresolution-concerning-some-major-issues-in-comprehensively-deepening-reform/

Chinn, Menzie D. and Jeffrey A. Frankel (2007): "Will the Euro Eventually Surpass the Dollar as Leading International Reserve Currency?”, in Richard Clarida (ed.): G7 Current Account Imbalances: Sustainability and Adjustment, University of Chicago Press, Chicago and London, 283-322.

Chow, Gregory C. (2003): “The Impact of Joining WTO on China's Economic, Legal and Political Institutions", Pacific Economic Review, Vol. 9 (2), pp. 105-115.

Cohen, Benjamin (1971): The Future of Sterling as an International Currency, Macmillan, London.

Cohen, Benjamin J. (1998): The Geography of Money, Cornell University Press, Ithaka and London.

Cohen, Benjamin J. (2000): "Life at the Top: International Currencies in the Twenty-First Century”, Essays in International Economics No. 221, Princeton University, Princeton, NJ.

Cohen, Benjamin J. (2012a): “The Yuan Tomorrow? Evaluating China’s Currency Internationalisation Strategy”, New Political Economy, 17 (3), 361-371.

Cohen, Benjamin J. (2012b): “The Benefits and Costs of an International Currency: Getting the Calculus Right", Open Economies Review, 23 (2), 13-31. 
Davis, Bob (2011): “Were China’s Leaders Conned?”, Wall Street Journal, June 2, http://online.wsj.com/news/articles/SB10001424052748703730804576313000018581 $\underline{230}$.

Dowd, Kevin and David Greenaway (1993): “Currency Competition, Network Externalities and Switching Costs: Towards an Alternative View of Optimum Currency Areas", The Economic Journal, Vol. 103 (420), pp. 1180-1189.

Economist (2012): "Finance: Bending not Breaking”, The Economist, May 26, http://www.economist.com/node/21555766

Economist (2013): “The New Prime Minister. A Talker or a Walker?”, The Economist, March 21, http://www.economist.com/news/china/21574023-despite-soundingebullient-li-keqiang-manages-expectations-downwards-talker-or$\underline{\text { walker?fsrc }=\text { nlw|wwp|3-21-2013|5342771|77780131|EU }}$

Eichengreen, Barry J. (2011): Exorbitant Privilege: The Rise and Fall of the Dollar and the Future of the International Monetary System, Oxford University Press, Oxford.

Eichengreen, Barry J., Ricardo Hausmann and Ugo Panizza (2005): “The Mystery of Original Sin", in Barry J. Eichengreen and Ricardo Hausmann (eds.): Other People's Money: Debt Denomination and Financial Instability in Emerging Market Economies, University of Chicago Press, Chicago and London, pp. 233-265.

Feyzioğlu, Tarhan, Nathan Porter and Előd Takáts (2009): “Interest Rate Liberalization in China”, IMF Working Paper No. 09/171, International Monetary Fund, Washington, DC.

Fratzscher, Marcel and Arnaud Mehl (forthcoming): "China's Dominance Hypothesis and the Emergence of a Tri-polar Global Currency System”, The Economic Journal.

Gao, Haihong (2012): “Convertibility as a Step for RMB Internationalization”, mimeo, CASS, Beijing. 
Gao, Haihong and Yongding Yu (2011): “Internationalisation of the Renminbi”, in: BIS and Bank of Korea (eds.): Currency Internationalisation: Lessons from the Global Financial Crisis and Prospects for the Future in Asia and the Pacific, Proceedings of a joint conference organised by the BIS and the Bank of Korea in Seoul on 19-20 March 2009, BIS Paper No.61, Bank for International Settlements, Basel, pp. 105-124.

Gao, Haihong and Ulrich Volz (2012): “中国是否准备好开放资本账户?” (Is China Ready to Open its Capital Account?), 新产经 (New Industrial Economy), June, p. 728.

Garcia-Herrero, Alicia and Le Xia (2013): “China's RMB Bilateral Swap Agreements: What Explains the Choice of Countries”, BOFIT Discussion Paper No. 12-2013, Bank of Finland, Helsinki.

Huang, Yukon (2012): “Grading China's Leadership: A for Intentions; F for Actions”,

Financial Times, April 3, http://carnegieendowment.org/2012/04/03/grading-china-sleadership-for-intentions-f-for-actions/a698

IMF (2012): “Bolstering the IMF's Lending Capacity”, International Monetary Fund,

Washington, DC, June 18, http://www.imf.org/external/np/exr/faq/contribution.htm Ito, Hiro and Ulrich Volz (2013): "China and Global Imbalances from a View of Sectorial Reforms", Review of International Economics, Vol. 21(1), 57-71.

Jeanne, Olivier (2005): “Why Do Emerging Economies Borrow in Foreign Currency?”, in Barry J. Eichengreen and Ricardo Hausmann (eds.): Other People's Money: Debt Denomination and Financial Instability in Emerging Market Economies, University of Chicago Press, Chicago and London, pp. 190-217.

Jefferson, Philip N. (1998): “Seigniorage Payments for Use of the Dollar: 1977-1995”, Economics Letters, Vol. 58 (2), pp. 225-230.

Kaplan, Stephen B. (2006): “The Political Obstacles to Greater Exchange Rate Flexibility in China”, World Development, Vol. 34 (7), pp. 1182-1200. 
Katada, Saori N. and Injoo Sohn (2012): "Regionalism as Financial Statecraft: Pursuit of Counterweight Strategies by China and Japan", Paper prepared for the "Pacific Rim Emerging Economies in the Post Global Financial Crisis" writers' workshop on July 27 and 28, 2012 at University of Southern California.

Kregel, Jan (2006): “Chances and Limits of South-South Monetary Coordination”, in Barbara Fritz and Martina Metzger (eds.): New Issues in Regional Monetary Coordination: Understanding North-South and South-South Arrangements, Palgrave, Houndmills, Basingstoke, pp. 42-53.

Kwan, Chi Hung (1994): Economic Interdependence in the Asia-Pacific Region: Towards a Yen Bloc, Routledge, London and New York.

Lardy, Nicholas (2012a): Sustaining China's Economic Growth after the Global Financial Crisis, Peterson Institute for International Economics, Washington, DC.

Lardy, Nicholas (2012b): "Sustaining Economic Growth in China”, East Asia Forum, February 5, http://www.eastasiaforum.org/2012/02/05/sustaining-economic-growth-inchinal

Liew, Leong H. and Harry X. Wu (2007): The Making of China's Exchange Rate Policy. From Plan to WTO Entry, Edward Elgar, Cheltenham.

Lin, Justin Yifu (2000): “China’s Accession to WTO: Impacts on Agriculture and Financial Sector", CCER Working Paper No. 2000-11, China Center for Economic Research, Peking University, Beijing.

Matsuyama, Kiminori, Nobuhiro Kiyotaki and Akihiko Matsui (1993): “Toward a Theory of International Currency”, Review of Economic Studies, Vol. 60 (2), pp. 283-307.

McKay, Julie and Ulrich Volz and Regine Wölfinger (2011): "Regional Financing Arrangements and the Stability of the International Monetary System”, Journal of Globalization and Development, Vol. 2 (1), Article 5. 
Minsky, Hyman P. (1986): Stabilizing an Unstable Economy, Yale University Press, New Haven.

Moore, Thomas G. (2002): China in the World Markets: Chinese Industry and International Sources of Reform in the Post-Mao Era, Cambridge University Press, Cambridge. Moses, Russell Leigh (2013): “A Significant Warning on Reform Roadblocks in China”, Real Time Economics, Wall Street Journal Online, December 8, http://blogs.wsj.com/economics/2013/12/08/a-significant-warning-on-reform$\underline{\text { roadblocks-in-china/?mod=WSJBlog }}$

People’s Daily (2013): “人民日报评论员：一分部署，九分落实一一三论贯彻落实十八届 三中全会精神 本报评论员” [Issuing one strategic plan is 10\% whereas the Actual Implementation of the Plan is 90\%], December 6, http://opinion.people.com.cn/n/2013/1206/c1003-23760285.html

Pettis, Michael (2011): “An Exorbitant Burden”, Foreign Policy, 7 September, http://carnegieendowment.org/2011/09/07/exorbitant-burden/51um

Pettis, Michael (2012): “China Needs a New Growth Model, Not a Stimulus”, Financial Times, 14 March, p. 9.

Pettis, Michael (2013): “What I will Watch in 2013”, China Financial Markets, 14 January. Prasad, Eswar and Lei Ye (2012): “The Renminbi’s Role in the Global Monetary System”, IZA Discussion Paper No. 6335, Institute for the Study of Labor, Bonn.

Rabinovitch, Simon (2012): “China's Banks are Still Not a Model for the World to Copy”, Financial Times, 21 March, p. 20.

Reade, J. James and Ulrich Volz (2012): “Chinese Monetary Policy and the Dollar Peg”, in Yin-Wong Cheung and Jakob de Haan (eds.): The Evolving Role of China in the Global Economy, MIT Press, Cambridge, MA, pp. 265-299.

Schobert, Franziska and Lijun Yu (forthcoming): “The Role of Reserve Requirements - The Case of Contemporary China Compared to Postwar Germany”, in Frank Rövekamp 
and Hanns Günther Hilpert (eds.), Currency Cooperation in East Asia, Springer, Berlin and Heidelberg.

Sender, Henny (2012): “China Should Give its People Greater Freedom on Investment”, Financial Times, March 30, p. 22.

Shambaugh, David (2011): "Coping with a Conflicted China", The Washington Quarterly, Vol. 34 (1), pp. 7-27.

Sheng, Songcheng (2012): “The Basic Conditions are Mature for Accelerating China's Capital Account Opening”, China Securities Journal, 23 February.

Shih, Victor (2012): “Awash in Debt: State Liabilities and Monetary and Welfare Implications for China”, mimeo, Northwestern University, Evanston, IL.

Subramanian, Arvind (2011): "Renminbi Rules: The Conditional Imminence of the Reserve Currency Transition”, PIIE Working Paper No. 11-14, Peterson Institute for International Economics, Washington, DC.

Subramanian, Arvind and Martin Kessler (2012): "The Renminbi Bloc is Here: Asia Down, Rest of the World to Go?”, PIIE Working Paper No. 12-19, Peterson Institute for International Economics, Washington, DC.

Taguchi, Hiroo (1994): “On the Internationalization of the Japanese Yen”, in Takatoshi Ito and Anne Krueger (eds.): Macroeconomic Linkage: Savings, Exchange Rates, and Capital Flows, University of Chicago Press, Chicago, IL, pp. 335-357.

Tavlas, George (1991): “On the International Use of Currencies: The Case of the Deutsche Mark”, Essays in International Finance No. 181, Princeton University, Princeton, NJ. Thimann, Christian (2010): “Global Roles of Currencies”, in Wensheng Peng and Chang Shu (eds.): Currency Internationalization: Global Experiences and the Implications for the Renminbi, Palgrave Macmillan, Houndsmills and Nerw York, NY, pp. 3-41. 
Unirule (2011): “Guoyou Qingye de Xingxhi, Baoxian yu Gaige” (The Nature, Performance, and Reform of State-owned Enterprises), Tianze (Unirule) Economic Research Institute Discussion Group, 12 April, http://unirule.org.cn/xiazai/2011/20110412.pdf

Volz, Ulrich and Manabu Fujimura (2009): “The Political Economy of Japanese Monetary and Exchange Rate Policy: With Special Reference to Regional Monetary Cooperation in East Asia", Economic Review, Vol. 1 (1), pp. 3-46.

Volz, Ulrich (2010): Prospects for Monetary Cooperation and Integration in East Asia, MIT Press, Cambridge, MA.

Volz, Ulrich (ed., 2012): Financial Stability in Emerging Markets: Dealing with Global Liquidity, German Development Institute, Bonn.

Volz, Ulrich (forthcoming): "RMB Internationalisation and Currency Co-operation in East Asia”, in Frank Rövekamp and Hanns Günther Hilpert (eds.), Currency Cooperation in East Asia, Springer, Berlin and Heidelberg.

Wei, Lingling (2013): “Beijing Lending Shift May Force Banks to Raise Capital”, Wall Street Journal, July 21.

Weston, Jonathan, Caitlin Campbell, and Katherine Koleski (2011): “China’s Foreign Assistance in Review: Implications for the United States", Staff Research Backgrounder, U.S.-China Economic and Security Review Commission, Washington, DC.

World Bank (2008): Building Bridges: China's Growing Role as Infrastructure Financier for Sub-Saharan Africa, World Bank, Washington, DC.

WSJ (2012): “China Takes on its Dinosaur Banks”, Wall Street Journal, April 5, p. C24.

WSJ (2013): “China Bank Shares Fall as Beijing Loosens Grip on Interest Rates”, China Real Time Report, Wall Street Journal Online, July 22, http://blogs.wsj.com/chinarealtime/2013/07/22/china-bank-shares-fall-as-beijing$\underline{\text { loosens-grip-on-interest-rates/?mod=djemChinaRTR_h }}$ 
Yu, Yongding (2012): "Revisiting the Internationalization of the Yuan”, ADBI Working Paper No. 366, Asian Development Bank Institute, Tokyo.

Zhu, Grace (2013): “Chinese Think Tank Puts Shadow Banking at 40\% of GDP”, Wall Street Journal China Real Time, October 9, http://blogs.wsj.com/chinarealtime/2013/10/09/chinese-think-tank-puts-shadowbanking-at-40-of-gdp/ 
Table 1: Framework of China's capital controls

\begin{tabular}{|c|c|c|c|}
\hline Major items & & Inflows & Outflows \\
\hline Direct investment & & \multicolumn{2}{|c|}{$\begin{array}{l}\text { Free; three-tier classification foreign exchange activities: } \\
\text { encouraged, restricted, prohibited }\end{array}$} \\
\hline \multirow[t]{2}{*}{ Stock market } & $\mathrm{NR}$ & $\begin{array}{l}\text { Local purchase of B shares } \\
\text { and QFIIs subject to a set of } \\
\text { limitations }\end{array}$ & $\begin{array}{l}\text { Sale of A, B share locally } \\
\text { with no restrictions and } \\
\text { QFIIs }\end{array}$ \\
\hline & $\mathrm{R}$ & $\begin{array}{l}\text { Sale of } \mathrm{B}, \mathrm{H}, \mathrm{N} \text { and } \mathrm{S} \text { shares } \\
\text { abroad and QDIIs locally }\end{array}$ & $\begin{array}{l}\text { QDIIs, insurance } \\
\text { companies, qualified banks } \\
\text { purchase abroad }\end{array}$ \\
\hline \multirow[t]{2}{*}{$\begin{array}{l}\text { Bonds and other } \\
\text { debt securities }\end{array}$} & $\mathrm{NR}$ & $\begin{array}{l}\text { QFIIs purchase locally } \\
\text { Purchase RMB bonds } \\
\text { offshore in HK, Singapore }\end{array}$ & $\begin{array}{l}\text { Financial and non-financial } \\
\text { firms, international agencies } \\
\text { issue RMB denominated } \\
\text { bonds in HK, Singapore and } \\
\text { locally }\end{array}$ \\
\hline & $\mathrm{R}$ & $\begin{array}{l}\text { Commercial and policy } \\
\text { banks, selected firms are } \\
\text { permitted to sale RMB bonds } \\
\text { in HK }\end{array}$ & $\begin{array}{l}\text { QDIIs, insurance } \\
\text { companies, qualified bank } \\
\text { purchase abroad }\end{array}$ \\
\hline \multirow[t]{2}{*}{ Money market } & $\mathrm{NR}$ & $\begin{array}{l}\text { QFIIs purchase money } \\
\text { market fund locally but no } \\
\text { permission to participate in } \\
\text { interbank FX market } \\
\text { Overseas monetary } \\
\text { authorities, the designated } \\
\text { RMB clearing banks and } \\
\text { participating banks to invest } \\
\text { in interbank bond market } \\
\text { with their legally acquired } \\
\text { RMB assets }\end{array}$ & No permission \\
\hline & $\mathrm{R}$ & $\begin{array}{l}\text { Bonds with less than one } \\
\text { year duration }\end{array}$ & QDIIs and qualified banks \\
\hline \multirow{2}{*}{$\begin{array}{l}\text { Collective } \\
\text { investment } \\
\text { securities }\end{array}$} & $\mathrm{NR}$ & $\begin{array}{l}\text { QFIIs purchase open-end and } \\
\text { close-end funds locally }\end{array}$ & No permission \\
\hline & $\mathrm{R}$ & Prior approval by SAFE & $\begin{array}{l}\text { QDIIs, insurance } \\
\text { companies, qualified banks } \\
\text { subject to quota }\end{array}$ \\
\hline \multirow{2}{*}{$\begin{array}{l}\text { Derivatives and } \\
\text { other instruments }\end{array}$} & $\mathrm{NR}$ & No permission & No permission \\
\hline & $\mathrm{R}$ & $\begin{array}{l}\text { Regulated financial } \\
\text { institutions with the approval } \\
\text { of CBRC may sell for the } \\
\text { purposes of hedging, gaining } \\
\text { profit, and providing } \\
\text { transaction services for } \\
\text { clients with limit on open } \\
\text { foreign exchange position } \\
\end{array}$ & Regulations on sale apply \\
\hline
\end{tabular}

Source: Adapted from Gao (2012).

Note: $R$ stands for residents; $N$ stands for non-residents; $Q F I I$ stands for Qualified Foreign Institutional Investors; QDIIs stands for Qualified Domestic Institutional Investors; SAFE is the State Administration of Foreign Exchange; $C B R C$ is the China Banking Regulatory Commission. 


\section{Table 2: Major steps toward RMB internationalization}

November 2002. Qualified Foreign Institutional Investors (QFII) can buy and sell RMB denominated shares in China's mainland stock exchanges, licensed by China Securities Regulatory Commission (CSRC). QFII investors need to obtain investment quotas from China's foreign currency regulator (SAFE) before they can start buying Chinese securities.

February 2004. Retail RMB business starts in Hong Kong and Macau (following permission given in November 2003). The PBOC provides clearing arrangement for relevant banks in Hong Kong and Macau via Bank of China Hong Kong and Macau.

October 2005. First two RMB-denominated bond from a non-Chinese issuer ("Panda bonds") are sold in mainland China by the International Finance Corporation and the Asian Development Bank.

May 2006. A PBOC Study Group publishes a report "Timing, Path, and Strategies of RMB Internationalization".

January 2007. RMB bonds (also known as "dim sum bonds") can be issued in Hong Kong.

July 2007. First dim sum bond issued by China Development Bank.

December 2008. Currency swap with South Korea.

December 2008. Premier Wen announces a pilot scheme of RMB cross border trade settlement with Hong Kong, Macau and ASEAN countries.

April 2009. State Council announces pilot program on RMB cross-border settlement in five cities. April 2009. First cross border trade settlement between Shanghai Silk group (China exporter) and Zhong Ye Trading (Hong Kong importer).

June 2009. PBOC and HKMA sign memorandum of cooperation for RMB cross-border trade settlement pilot scheme.

July 2009. PBOC and other five authorities issued administrative rules for RMB settlement pilot scheme with HK, Macau and ASEAN countries.

July 2009. Launch of the pilot scheme for RMB cross border trade settlement between Mainland Designated Enterprises (MDEs) in five cities (Shanghai, Guangzhou, Shenzhen, Dongguan and Zhuhai) and corporations in Hong Kong, Macau and ASEAN countries.

September 2009. Ministry of Finance issues the first sovereign RMB-denominated bond in Hong Kong.

November 2009. Interbank Market Clearing House is founded in Shanghai.

March 2010. PBOC and the National Bank of Belarus sign local-currency settlement agreement, the first of its kind with a non-neighboring country.

May 2010. Rules for issuance of Panda bonds are liberalized and more issuers are allowed. Bank of Tokyo-Mitsubishi UFJ (China) Ltd. is the first foreign bank to sell bonds in China.

June 2010. RMB trade settlement program is extended to 20 provinces and to trading partners world-wide.

June 2010. RMB bonds extended to allow banks to develop all types of RMB products and open type of participation to all types of financial intermediaries.

July 2010. Bank of China (Hong Kong) authorized to clear RMB bank notes in Taiwan.

July 2010. Hong Kong financial institutions allowed to open RMB accounts.

July 2010. Hopewell Highway issues the first corporate RMB-denominated bond in Hong Kong. August 2010. First offshore RMB mutual fund is started.

August 2010. Qualified financial institutions (overseas central banks, cross border settlement banks, RMB clearing banks) can invest in China's interbank bond market. 
September 2010. First foreign-issued dim sum bond by a nonfinancial company (McDonald's) in Hong Kong.

October 2010. Overseas institutions allowed to apply for RMB accounts for trade settlement.

October 2010. Pilot project for deposits of export proceeds abroad launched in four areas.

October 2010. Asian Development Bank issues first supranational dim sum bond.

December 2010. Trade settlement scheme expanded; number of Chinese exporters eligible for cross-border settlement (MDEs) rises from 365 to 67,359.

January 2011. PBOC announces a pilot scheme under which residents of 20 provinces and cities are allowed to use RMB for outward FDI.

January 2011. Bank of China allowed to offer RMB deposit accounts in New York City.

April 2011. First RMB IPO by Hui Xian, listed on the Hong Kong Exchange.

August 2011. Cross-border trade settlement in RMB is extended to the whole nation.

August 2011. Initial RMB 20bn Mini-QFII Program launched.

September 2011. At the UK-China Economic and Financial Dialogue Vice Premier Wang Qishan and British Chancellor of the Exchequer George Osborne agree on a cooperation project on the development of RMB-denominated products and services in London and welcome a private sector-led development of the offshore RMB market in London.

October 2011. Banks are allowed to provide settlement services to overseas entities that made RMB denominated investments.

November 2011. JP Morgan Asset Management is allowed to create a \$1bn RMB-denominated fund under the Qualified Limited Partners Program, making it the largest foreign manager of an RMB-denominated fund so far.

December 2011. China and Japan sign currency pact to promote use of their currencies for bilateral trade and investment flows.

January 2012. Shanghai city government and NDRC outline a plan for developing the size of the city's capital markets and open them more widely to foreign investors by 2015 .

April 2012. China Securities Regulatory Commission announces an expansion of the QFII scheme from the previous limit of $\$ 30 \mathrm{bn}$ to $\$ 80 \mathrm{bn}$ and increases the total amount of RMB that foreign investors can raise in Hong Kong for investment on the mainland from RMB20bn to RMB70bn.

April 2012. HSBC issues a three-year RMB-denominated bond in London, the first dim sum bond to be issued outside China and Hong Kong.

June 2012. Announcement of plans to create a special zone to experiment with currency convertibility in Shenzhen.

November 2012. First Chinese bank (China Construction Bank) issues RMB-denominated bond in London.

January 2013. Qianhai, a special zone located in the western part of Shenzhen, is allowed to launch China's first cross-border RMB lending programme (with Hong Kong). 15 banks in Hong Kong - nine branches of mainland lenders and six foreign banks - sign \$320m RMB loans to Chinese mainland firms relating to 26 projects registered in Qianhai.

May 2013. The State Council announces that by the end of the year the government would outline a plan for full convertibility of the RMB.

July 2013. The State Council announces the intention to establish a pilot zone in Shanghai as a test ground for financial reforms, including interest rate liberalization and full convertibility of the RMB.

October 2013. Singapore-based investors are allowed to buy RMB-denominated securities. 
November 2013. China's biggest bank (Industrial and Commercial Bank of China) issues its first dim sum bond in London.

Source: Based on Volz (2013) and Prasad and Ye (2012) and amended and updated by the author. 
Table 3: Bilateral swap agreements with other central banks (as of December 2013)

\begin{tabular}{|c|c|c|c|}
\hline Country/area & $\begin{array}{c}\text { Amount (in } \\
\text { billion RMB) }\end{array}$ & Date of agreement & Expiration date \\
\hline Albania & 2 & September 2013 & September 2016 \\
\hline Argentina & 70 & March 2009 & March 2012 \\
\hline Australia & 200 & March 2012 & March 2015 \\
\hline Belarus & 20 & March 2009 & March 2012 \\
\hline Brazil & 190 & March 2013 & March 2016 \\
\hline Eurozone (ECB) & 350 & October 2013 & October 2013 \\
\hline Hong Kong & $\begin{array}{l}200 \\
400\end{array}$ & $\begin{array}{c}\text { January } 2009 \\
\text { November } 2011\end{array}$ & $\begin{array}{c}\text { January } 2012 \\
\text { November } 2014\end{array}$ \\
\hline Hungary & 10 & September 2013 & September 2016 \\
\hline Iceland & 3.5 & June 2010 & June 2013 \\
\hline Indonesia & 100 & March 2009 & March 2012 \\
\hline Kazakhstan & 7 & June 2011 & June 2014 \\
\hline Korea & $\begin{array}{l}180 \\
360 \\
360\end{array}$ & $\begin{array}{c}\text { December } 2008 \\
\text { October } 2011 \\
\text { June } 2013\end{array}$ & $\begin{array}{c}\text { December } 2011 \\
\text { October } 2014 \\
\text { October } 2017\end{array}$ \\
\hline Malaysia & $\begin{array}{c}80 \\
180\end{array}$ & $\begin{array}{l}\text { February } 2009 \\
\text { February } 2012\end{array}$ & $\begin{array}{l}\text { February } 2012 \\
\text { February } 2015\end{array}$ \\
\hline Mongolia & $\begin{array}{c}5 \\
10 \\
\end{array}$ & $\begin{array}{c}\text { May } 2011 \\
\text { March } 2012 \\
\end{array}$ & $\begin{array}{l}\text { May } 2014 \\
\text { May } 2014 \\
\end{array}$ \\
\hline New Zealand & 25 & April 2011 & April 2014 \\
\hline Pakistan & 10 & December 2011 & December 2014 \\
\hline Russia & $\begin{array}{l}\text { Local currency } \\
\text { settlement } \\
\text { agreement, no } \\
\text { limitation }\end{array}$ & June 2011 & \\
\hline Singapore & $\begin{array}{l}150 \\
300 \\
\end{array}$ & $\begin{array}{c}\text { July } 2010 \\
\text { March } 2013\end{array}$ & $\begin{array}{c}\text { July } 2013 \\
\text { March } 2016\end{array}$ \\
\hline Turkey & 10 & February 2012 & February 2015 \\
\hline Thailand & 70 & December 2011 & December 2014 \\
\hline United Arab Emirates & 35 & January 2012 & January 2015 \\
\hline United Kingdom & 200 & June 2013 & June 2016 \\
\hline Ukraine & 15 & June 2012 & June 2015 \\
\hline Uzbekistan & 0.7 & April 2011 & April 2014 \\
\hline
\end{tabular}

Source: Compiled by author with enhanced and updated data from Garcia-Herrero and Xia (2013). 